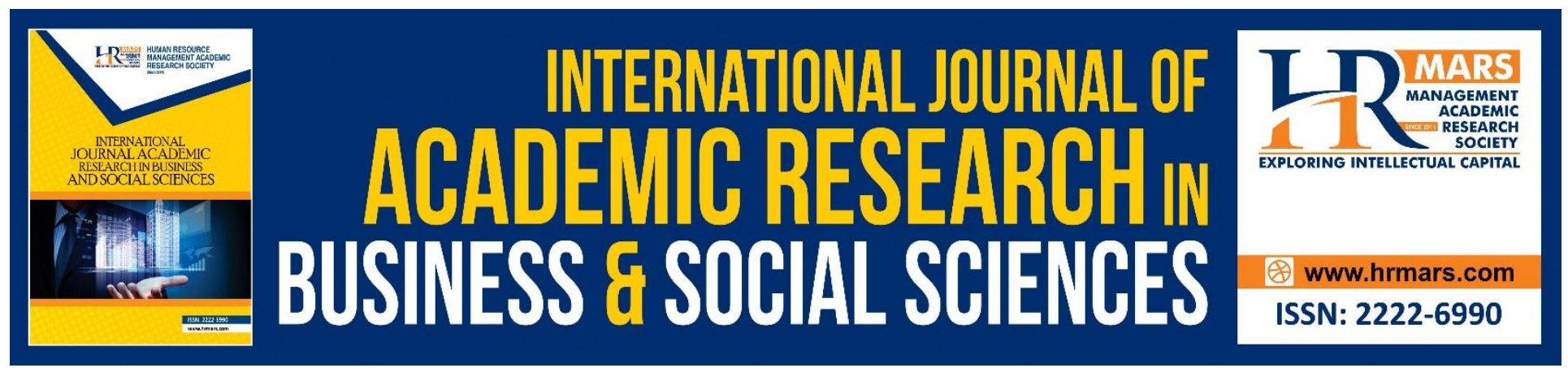

\title{
Insights into Developing 3D Visualization Technology to Enhance Gen Y Engagement in Agriculture
}

\author{
Jeffrey Lawrence D’Silva, Ismi Arif Ismail, Dzuhailmi Dahalan, Zeinab \\ Zaremohzzabieh, Steven Eric Krauss
}

To Link this Article: http://dx.doi.org/10.6007/IJARBSS/v11-i15/10645

DOI:10.6007/IJARBSS/v11-i15/10645

Received: 11 May 2021, Revised: 15 June 2021, Accepted: 02 July 2021

Published Online: 25 July 2021

In-Text Citation: (D'Silva et al., 2021)

To Cite this Article: D’Silva, J. L., Ismail, I. A., Dahalan, D., Zaremohzzabieh, Z., \& Krauss, S. E. (2021). Insights into Developing 3D Visualization Technology to Enhance Gen Y Engagement in Agriculture. International Journal of Academic Research in Business and Social Sciences, 11(15), 185-196.

\section{Copyright: (c) 2021 The Author(s)}

Published by Human Resource Management Academic Research Society (www.hrmars.com)

This article is published under the Creative Commons Attribution (CC BY 4.0) license. Anyone may reproduce, distribute, translate and create derivative works of this article (for both commercial and non-commercial purposes), subject to full attribution to the original publication and authors. The full terms of this license may be seen at: http://creativecommons.org/licences/by/4.0/legalcode

Special Issue: Empowering Youth and Community Wellbeing for Sustainable Development, 2021, Pg. 185 - 196 http://hrmars.com/index.php/pages/detail/IJARBSS

Full Terms \& Conditions of access and use can be found at http://hrmars.com/index.php/pages/detail/publication-ethics 


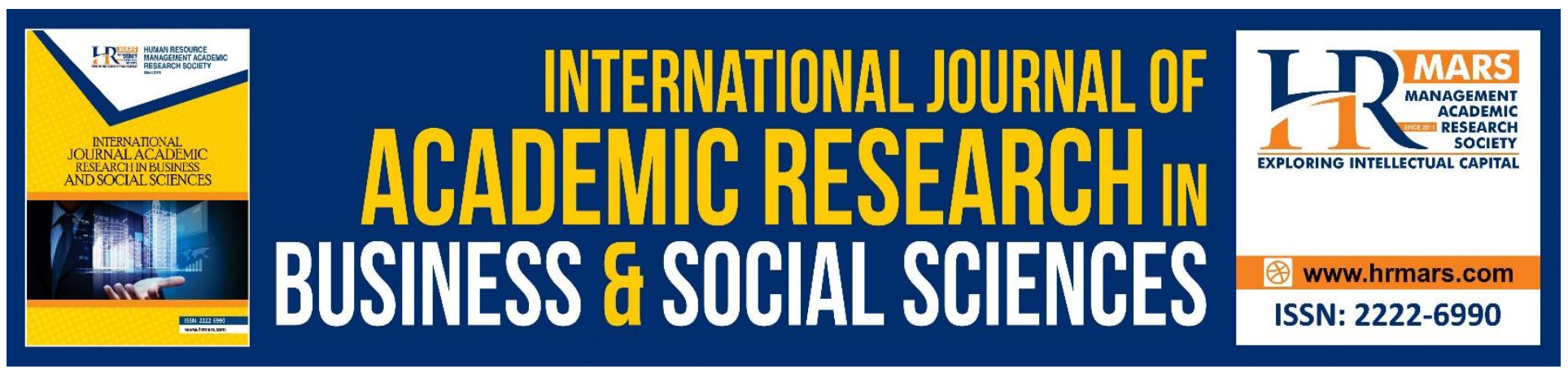

\title{
Insights into Developing 3D Visualization Technology to Enhance Gen $Y$ Engagement in Agriculture
}

\author{
Jeffrey Lawrence D'Silva \\ Laboratory of Youth Citizenship \& Leadership, Institute for Social Science Studies, Universiti Putra \\ Malaysia, 43400, UPM, Serdang, Selangor, Malaysia. \\ Email: jld@upm.edu.my
}

Ismi Arif Ismail, Dzuhailmi Dahalan, Zeinab Zaremohzzabieh Institute for Social Science Studies, Universiti Putra Malaysia, 43400, UPM, Serdang, Selangor, Malaysia.

Email: ismi@upm.edu.my, ipsas@upm.edu.my,zeinabzaremohzzabieh@gmail.com

\section{Steven Eric Krauss}

Professional Development \& Continuing Education's Department, Institute for Social Science Studies, Universiti Putra Malaysia, 43400, UPM, Serdang, Selangor, Malaysia.

Email: lateef@upm.edu.my

\begin{abstract}
Sustainable Development Goals 2030 emphasizes the need for sustainable agriculture and consequently modern technologies play an important role to attain this agenda. The young generation of farmers are more inclined towards farming with greater usage of technology such as $3 \mathrm{D}$ visualization technology. Thus, the objective of this study is to determine the attributes for the development of a 3D technology on sustainable farm management among young farmers. Past studies were used as the mechanism to provide data for this research. The outcome from this study is three pathways are provided for future research on development of 3D visualization technology to further enhance Gen $Y$ engagement in agriculture.
\end{abstract}

Keywords: Agriculture, Visualization Technology, Youth

\section{Introduction}

Youth plays an important role in the future development of agriculture and a recent study indicated youth prefer enhanced usage of modern technologies for agriculture sustainability (D'Silva et al., 2020). Sustainability is a characteristic of a process or state that can be maintained at a certain level indefinitely. The term, in its environmental usage, refers to the potential longevity and durability of vital human ecological support systems, such as the planet's climatic system, systems of agriculture, industry, forestry, fisheries, and the systems on which they depend. 
Sustainable farming management refers to the ability of a farm to produce food indefinitely, without causing irreversible damage to ecosystem health. Sustainability in agriculture refers to the farm's ability to maintain and conserve production and offer benefits based on maintaining nature and the environment, accelerating social growth, stabilizing the economy and being commercially good competitor in the fast changing environment (Malappa \& Babu, 2021; D'Silva, Samah, \& Shaffril, 2012; D'Silva et al., 2011; D'Silva et al., 2010; Ismail, 2006). Further, achieving a sustainable farming practice is one of the most important goals for the near future (FAO, 2019).

Young farmers constitute a formidable force for sustainable agricultural development of any nation, particularly the agrarian ones (Iwala, 2006). Unsustainable production practices are causing water scarcity, soil erosion, loss of biodiversity and pest resistance to pesticides, among other environmental problems, in many agricultural systems worldwide. In addition, the depletion of the ecosystem's health and services is often intertwined with health, food security and poverty issues, especially in the most marginal rural areas in developing countries (Thompson et al., 2007).

\section{The 3D Technology and Sustainable Farm Management}

The importance of information technology in precision farming is well established in research with studes such as Munack and Speckmann (2001) and Santana et al. (2007) supporting it. In Malaysia, the priority is also in using ICTs and new technologies in farm management, so as to increase food crop production and increase farmers' income (Adnan, Nordin \& Ali, 2018). Paddy yields have been increasing since the 1960s, but since the 1990s, the increase in rice production has been slower than population growth (Othman, 2012).

The management of paddy farms is becoming more complex day to day. Paddy farmers are searching for alternatives intervention strategies and appropriate governance of agricultural systems compared to current agricultural practices in order to reduce environmental risk and increase profit margins. Generally, sustainable paddy farming can be summarized into four main categories, namely: balancing the ecosystem; input from sustainable resources, producing costumers' friendly products (e.g. green products), and natural control of paddy farms (e.g. natural control of pests, diseases and weeds) (Sharghi, Sedighi, \& Eftekhari, 2010). Until recently, the choice of technologies available to farmers was largely determined by the need to increase production, profits and productivity (OECD, 2001). According to Othman and Muhammad (2011), 3D technology can be used for every eight major steps in sustainable paddy farming practices, namely: land preparation, selecting seeds, managing water, apply fertilizers, control weeds, control pest and disease control, and harvesting.

One of the biggest obstacles for developing and implementing 3D technology is the lack of education and awareness among young paddy farmers (Adnan, Nordin, \& Ali, 2018). Much effort and research is needed that would contribute towards a better understanding of how spatial technologies such as the 3D farmer's technology tools can be used to make more informed and sustainable farm and catchment management decisions. Technologies are increasingly being developed in a global market, applied at the farm level but impacting on sustainability beyond the farm. This 3D technology must be able to help young paddy farmers to manage data farms as well as exchange data with services that provide multiplication for care farming. Both conventional and latest technologies, in particular related to biotechnology, information and precision farming techniques, are global businesses. The 3D technology was preferred because of its interactive and collaborating ability to disseminate 
information to farmers and other people. Its interactive ability will help in developing and enriching agricultural product along with well-being of the farmers. It will also help in reducing the global hunger in rural community.

However, technological developments are rapidly evolving and information on the costs and benefits of adopting technologies in agriculture is often imperfect. The 3D technology offers a potential way to more easily navigate and interpret farm management information. Consequently, future research is required to inquire on youth paddy farmers to adopt 3D technology on sustainable farm management. According to Alessi \& Trollip's (2001) Model of Instructional Design, there are three main components in this model: planning, design and development (see Figure 1).

Figure 1: Alessi \& Trollip (2001) Model of Instructional Design

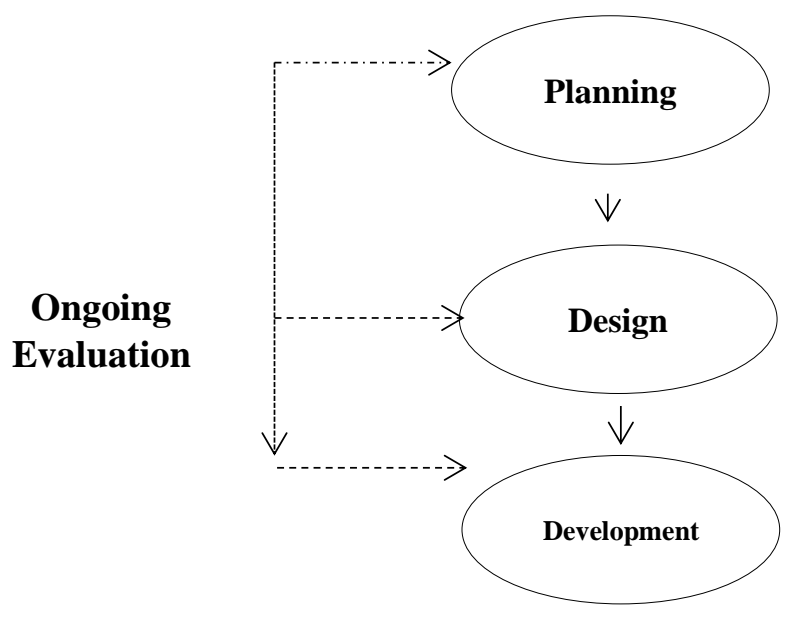

The design and development of 3D technology for sustainable farm management is a micro strategy. These micro strategies are concerned with the individual displays, including their characteristics, interrelationship and sequence that are to be presented to the learners. Micro strategies may also be characterized as presentation strategies because they are concerned with the details of each individual presentation to the learner (Chen, 2005).

Therefore, in an effort to develop of 3D technology on sustainable farm management among young paddy farmers, many questions might be of interest: Are young paddy farmers able to adopt 3D technology on sustainable farm management? What is the present knowledge and skills of young paddy farmers towards 3D visualization technology on sustainable farm management? How can Agriculture Department Agencies (ADAs) play a vital role empower farmers to use 3D technology on sustainable farm management? Such questions will gear towards the development of the 3D technology on sustainable farm management that is in line with the needs, knowledge and skills of young farmers.

In line with the above questions, there are three-fold objectives in this paper that will provide the pathway for future researchers to embark in different projects, namely, (i) to determine predictors on participation of farmers towards implementing 3D visualization technology on sustainable farm management; (ii) to develop modeling knowledge and skills development towards 3D visualization technology on sustainable farm management, and (iii) to determine the role of agriculture 
INTERNATIONAL JOURNAL OF ACADEMIC RESEARCH IN BUSINESS AND SOCIAL SCIENCES

Vol. 11, No. 15, Empowering Youth and Community Wellbeing for Sustainable Development, 2021, E-ISSN: 2222-6990 @ 2020 HRMARS

department agencies to empower young farmers to use 3D visualization technology on sustainable farm management.

\section{Methodology}

This is an exploratory study whereby past studies were used to determine the pathway to achieve the objectives of the study. Based on these studies as well as the theories used, various farming approaches using the 3D visualization technology was investigated and synthesized that will yield the appropriate directions for future research.

\section{Results}

The first objective of this study is to determine predictors on participation of farmers towards implementing 3D visualization technology on sustainable farm management. Thus, the purpose is to evaluate the farmers' intention to 3D visualization technology on sustainable farm management.

Many policies, including those relating to agriculture, environment, and research and development, provide a combination of incentives and disincentives to technology adoption. We believe that including the dynamic dimension of evolving farming systems can make an important contribution to understanding how farming systems can be more sustainable in a way of innovation.

We distinguish between three broad approaches that coexist in the farm management discourse: the engineering approach, the farming systems approach, and the adaptive management approach. These three are loosely defined and we are aware that we cannot do justice to the wide variety of disciplinary refinements. The theories that might be used to inform an adaptive perspective of farm management are evolutionary theory and complexity theory. Evolutionary theories have mostly been developed in ecology. In the context of farms, these theories can help explain how farms generate and adapt to change, and how these processes are intertwined with what happens both at the level of individual farms and the higher level of markets and the farm's environment in general (see Rathe \& Witt, 2001).

The theory of complex adaptive systems has been taken up by some researchers in economics and management sciences (e.g., Anderson, 1999; Meyer, Gaba, \& Colwel, 2005; Teece, 2007; Walsh, Meyer, \& Schoonhoven, 2006), as well as in other social sciences (Stewart, 2001; Urry, 2005). For example, Socio-psychological models of social cognitive behavior are useful in this regard and one in particular, the Theory of Planned Behavior (TPB; Ajzen 1991), dominates the literature (e.g., Beedell \& Rehman, 2000; Burton, 2004). This theory proposes that three key components influence intent to perform a behavior, namely: attitudes toward the behavior, subjective norms (SNs; the degree to which one feels that significant others think one should perform the behavior), and perceived behavioral control (PBC; the degree to which one feels able to perform the behavior). Each of these concepts is predicted by specific beliefs and evaluations about the outcomes of behavior (for the attitude), the different persons or groups who are relevant to the person (for subjective norm) and the potential skills, opportunities, and barriers one thinks are relevant for performing the behavior (for perceived behavioral control). The extent to which attitude, subjective norm, and perceived behavioral control independently influence behavior is not fixed, but is dependent on the psychology of the individual, the behavior in question and the context in which it is performed. In addition, other components have been found to contribute to explaining the variance in intention and behavior. For 
INTERNATIONAL JOURNAL OF ACADEMIC RESEARCH IN BUSINESS AND SOCIAL SCIENCES

Vol. 11, No. 15, Empowering Youth and Community Wellbeing for Sustainable Development, 2021, E-ISSN: 2222-6990 @ 2020 HRMARS

example, studies of pro-environmental behavior have shown that personal norm plays an influential role (Bamberg \& Möser, 2007; Harland, Staats, \& Wilke, 2007). See Figure 1.

Figure 1: Theory of planned behaviour adopted from Ajzen (1991).

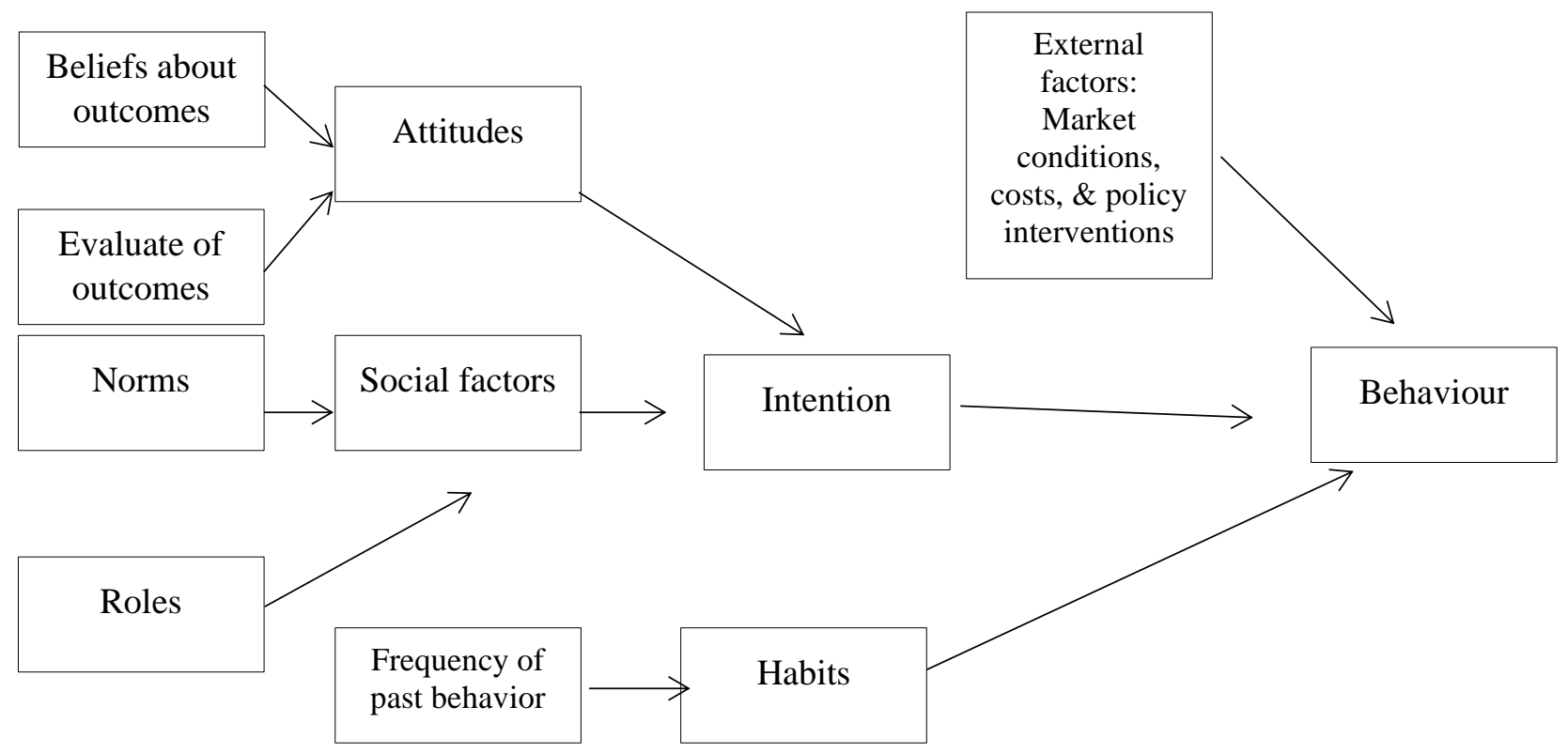

There are many theories to investigate the behavior of users in adopting new technologies such as the theory of reasoned action, theory of planned behavior (TPB), and the technology acceptance model (TAM; Benham \& Raymond, 1996; Limthongchai \& Speece, 2003; M. Tan \& Teo, 2000). This has resulted in different outcomes. However, prior studies concluded that while diffusion of innovation (DOI) remains a popular model (K. S. Tan, Chong, \& Uchenna, 2009). In fact, it has been identified that studies using DOI alone yielded different results (Hussin \& Noor, 2005; Kendall, Tung, Chua, Ng, \& Tan, 2001; Lim \& Speece, 2003). It attempted to predict the adoption behaviour of individuals by looking at their personal characteristics, the time factor and the characteristics of the innovation itself.

The DOI model was, for a long time, the main theoretical model for agricultural extension and the development of agricultural advisory services (Albrecht, 1980; Vanclay \& Lawrence, 1994). Rogers (2003, p. 150) proposes that four main elements influence the spread of a new idea: the innovation itself, communication channels, time, and a social system. This process relies heavily on human capital. The innovation must be widely adopted in order to self-sustain. Within the rate of adoption, there is a point at which an innovation reaches critical mass. The categories of adopters are: innovators, early adopters, early majority, late majority, and laggards (see Table 1). The study also could understand that young farmers are in which stages of adopting 3D visualization technology when it will be introduced to them. 
Table1: The categories of adopters (Rogers, 2003).

\begin{tabular}{|c|c|}
\hline $\begin{array}{l}\text { Adopter } \\
\text { Category }\end{array}$ & Definition \\
\hline Innovators & $\begin{array}{l}\text { Innovators are willing to take risks, have the highest social status, have } \\
\text { financial liquidity, are social and have closest contact to scientific sources } \\
\text { and interaction with other innovators (Rogers, 2003, p. 282). }\end{array}$ \\
\hline $\begin{array}{l}\text { Early } \\
\text { adopters }\end{array}$ & $\begin{array}{l}\text { These individuals have the highest degree of opinion leadership among the } \\
\text { adopter categories. They have a higher social status, financial liquidity, } \\
\text { advanced education and are more socially forward than late adopters } \\
\text { (Rogers, 2003, p. 283). }\end{array}$ \\
\hline $\begin{array}{l}\text { Early } \\
\text { Majority }\end{array}$ & $\begin{array}{l}\text { They adopt an innovation after a varying degree of time that is significantly } \\
\text { longer than the innovators and early adopters. They have above average } \\
\text { social status, contact with early adopters and seldom hold positions of } \\
\text { opinion leadership in a system (Rogers, 2003, p. 283) }\end{array}$ \\
\hline $\begin{array}{l}\text { Late } \\
\text { Majority }\end{array}$ & $\begin{array}{l}\text { They adopt an innovation after the average participant. These individuals } \\
\text { approach an innovation with a high degree of skepticism and after the } \\
\text { majority of society has adopted the innovation. }\end{array}$ \\
\hline Laggards & $\begin{array}{l}\text { They are the last to adopt an innovation. Laggards typically tend to be } \\
\text { focused on "traditions", lowest social status, lowest financial liquidity, oldest } \\
\text { among adopters, and in contact with only family and close friends. }\end{array}$ \\
\hline Leapfroggers & $\begin{array}{l}\text { When resistors upgrade they often skip several generations in order to reach } \\
\text { the most recent technologies. }\end{array}$ \\
\hline
\end{tabular}

Rogers (2003) considers five stages in which a serious of different actions that occur over time to evaluate a new idea by an individual or system to decide either to incorporate the innovation into ongoing practice or not. The first stage is knowledge which refers to young farmers understanding of how the innovation functions. The second stage is persuasion that relates to the young farmers attitude about innovation. The third stage is decision in which a young farmer chooses to adapt or reject the innovation (see Figure 2). 
Figure 2: Three out of five stages in the innovation-decision process (Rogers, 2003, p. 170)

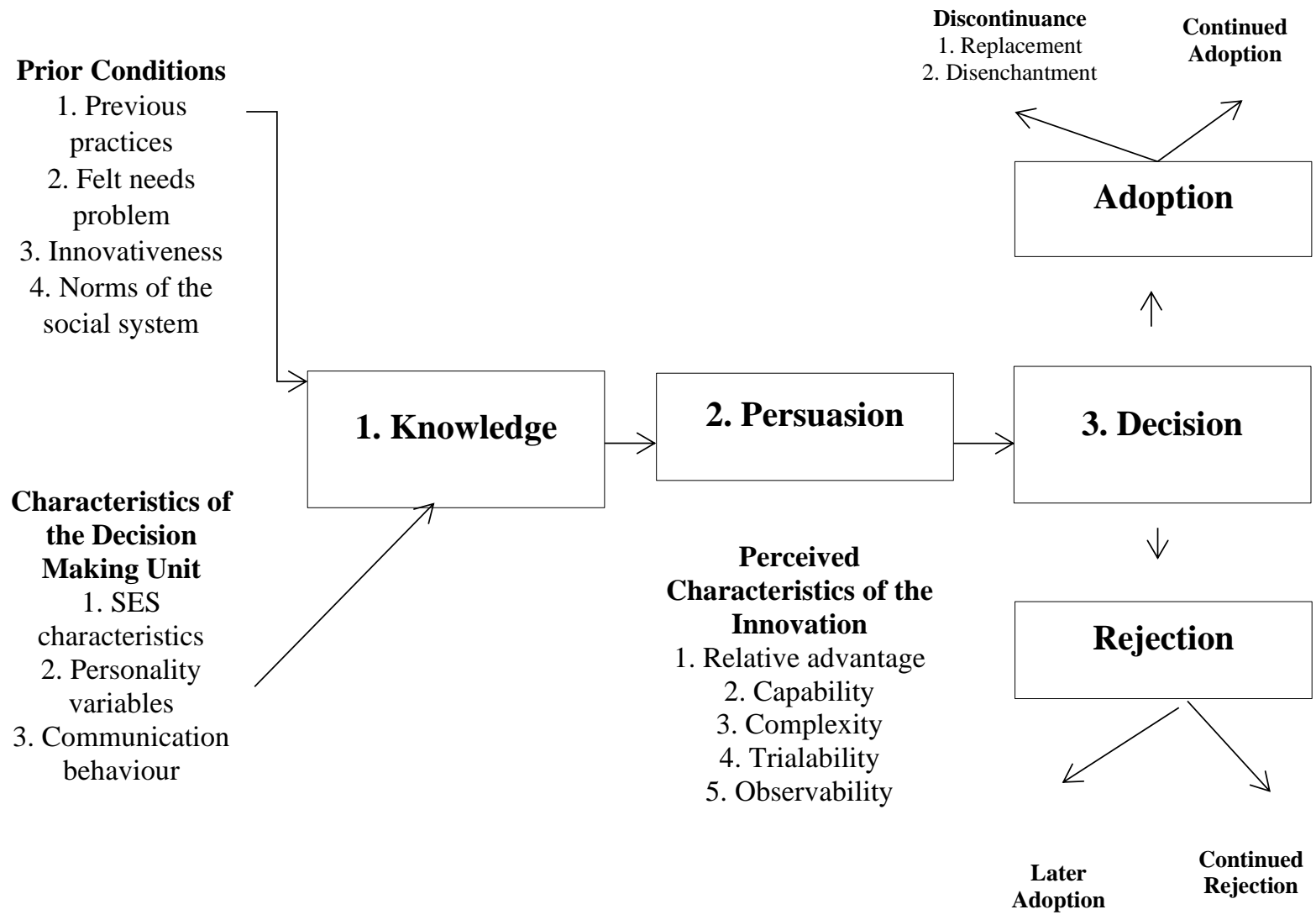

It is expected that these theories contribute towards facilitating the adoption of sustainable farm technologies (e.g., 3D visualization technology). This is particularly significant as such adoption requires a change of mindset of the public through various theories, including effective education and information dissemination to increase public awareness of sustainable agriculture and on ways to conserve the sustainable farm management among young farmers.

The second objective of this study is to develop modeling knowledge and skills development towards 3D visualization technology on sustainable farm management meaning the study will be on 3D visualization technology and the work is virtual in nature. It explains the necessity of considering and articulating accurately and synergistically relationships of different subsystems in the current agricultural knowledge and information systems that affect the farmers participation, information technologies and other related technologies in the agriculture to achieve more socially, economically and environmentally sustainable agriculture.

There are a range of farm management systems and spatial technologies to assist farmers in making better land use decisions such as Google Earth (Obiniyi \& Ibrahim, 2015; Taylor \& Lovell, 2012; Trujillo, Piroddi, \& Jacquet, 2012) and Geographic Information Systems (GIS; Pierce \& Clay, 2007) in sustainable farm management. Therefore, information obtained from this study will provide in which position the farmers are in the process of understanding 3D visualization technology. To effectively engage in sustainable farm management, adequate mechanisms or approaches (Figure 3) are needed 
for generating, capturing, and disseminating knowledge and information through the use of 3D visualization technology.

Modeling the knowledge and skills towards 3D visualization technology of young farmers could be developed through following process: (i) identification of current knowledge of young farmers towards 3D visualization technology; (ii) recognition of skills of young farmers towards 3D visualization technology; and (iii) adding data from the need analysis - Functions and information that young farmers want and need from 3D visualization technology.

Figure 3. Knowledge Management Process (Cong, Li-Hua, \& Stonehouse, 2007).

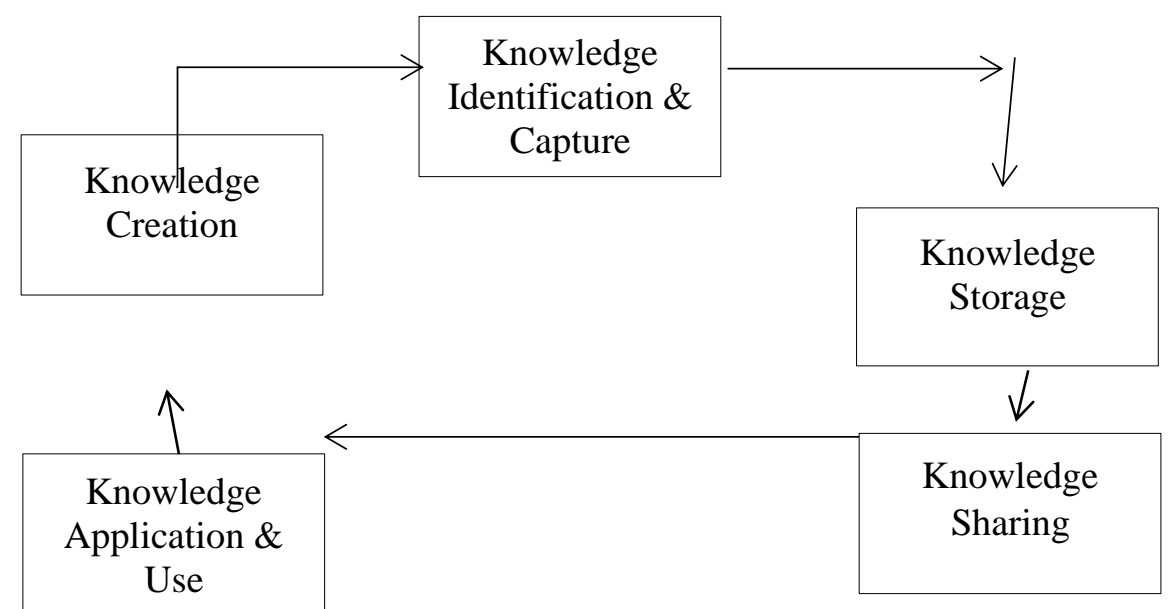

The third objective of this study is determining the role of agriculture department agencies to empower farmers to use 3D visualization technology on sustainable farm management. To speed up 3D visualization technology adoption, the Agriculture Department Agencies (ADAs) need to review and modernize its farming management system and particularly the sustainable farm management and provide an enabling framework for utilizing advances in the 3D visualization technology to the sustainable farm management.

According to Arshad et al., (1988), the roles of Agriculture Department Agencies (ADAs) are to direct and enforce R\&D in new emerging areas (e.g., 3D visualization technology). Using 3D visualization technology will not only improve information and knowledge management for farmers but optimize and rationalize public resources devoted to decision farm systems. This project will be able to analyze the government's medium-term vision and the role of Agriculture Department Agencies to empower farmers to use $3 \mathrm{D}$ visualization technology on sustainable farm management.

The analysis can focus with a review of sustainable agricultural productivity from a comparative perspective and examines the potential improvements that can be realized by improving 3D visualization technology adoption and use by smallholder farmers. This assessment provides a basis for analyzing strategies for attaining productivity targets in the smallholder's farm segment which substantially underpins the country's food security goals.

Streamlining sustainable farm management has been identified as one of the critical interventions that will drive 3D visualization technology adoption and use by smallholder farmers. In this regard, 
reviewing the country's farm management system will be critical in identifying gaps and areas where strategic improvements needs to be made to enable improved information management to contribute to raising sustainable agriculture productivity and ensuring food security in the country. Such strategies will focus, among others, on innovative approaches for embracing modern ICT based sustainable farm management to speed up agricultural technology and market information dissemination to farmers and other stakeholders in the agricultural sector.

\section{Conclusion}

This paper provides insights into long-term sustainability of agriculture using technology that is in line with the attainment of Sustainable Development Goals 2030. It offers the platform for future researchers to gain knowledge on the required information to develop 3D visualization technology for young farmers that is in line with their participation, knowledge, and skills. Besides, it explains the effectiveness of the 3D visualization technology for young farmers particularly information on things that should be included and excluded to further improved 3D visualization technology development.

It is believed that research on 3D visualization technology has a great impact since the 3D visualization technology can further enhance young farmers' income, sustain farming management, improve plant cropping, etc., the project on development 3D visualization technology is able to generate income money as it has the ability to attract interests from other Agricultural Department Agencies (ADAs) to use and develop 3D visualization technology for young farmers, and its impact on nation will be to increase the capability of the agricultural sector to play its strategic role in national development is sustained and enhanced in light of new and emerging challenges facing agricultural development and to enhance food security for the nation.

\section{Acknowledgments}

This research was supported by the Research Management Centre, Universiti Putra Malaysia (GPB/2018/9597700).

\section{References}

Adnan, N., Nordin, S. M., \& Ali, M. (2018). A solution for the sunset industry: Adoption of Green Fertiliser Technology amongst Malaysian paddy farmers, Land Use Policy, 79: 575-584.

Ajzen, I. (1991). The theory of planned behavior. Organizational Behavior and Human Decision Processes, 50(2), 179-211.

Albrecht, H. (1980). Diffusion processes and social structure: Review of research within rurual sociology. In H. J. Hummel \& W. Sodeur (Eds.), Modelle für Ausbreitungsprozesse in sozialen Strukturen (pp. 39-51). Bad Homberg: Verlag der Sozialwissenschaftlichen Kooperative.

Anderson, P. (1999). Perspective: Complexity theory and organization science. Organization Science, 10(3), 216-232.

Arshad, F. M., Rahman, A. A. A., Fee, W. L., \& Yoong, W. C. (1988). Malaysian agriculture policy: Issues and directions. Kuala Lumpur, Malaysia: Percetakan Sinar Surya.

Bamberg, S., \& Möser, G. (2007). Twenty years after Hines, Hungerford, and Tomera: A new metaanalysis of psycho-social determinants of pro-environmental behaviour. Journal of Environmental Psychology, 27(1), 14-25.

Beedell, J., \& Rehman, T. (2000). Using social-psychology models to understand farmers' conservation behaviour. Journal of Rural Studies, 16(1), 117-127. 
Benham, H. C., \& Raymond, B. C. (1996). Information technology adoption: evidence from a voice mail introduction. ACM SIGCPR Computer Personnel, 7(1), 3-25.

Burton, R. (2004). Reconceptualising the "behavioural approach" in agricultural studies: a sociopsychological perspective. Journal of Rural Studies, 20, 359-371.

Cong, X., Li-Hua, R., \& Stonehouse, G. (2007). Knowledge management in the Chinese public sector: empirical investigation. Journal of Technology Management in China, 2(3), 250-263.

D'Silva, J. L., Dahalan, D., Zaremohazzabieh, Z., Ismail, I. A., \& Krauss, S. E. (2020). Socio-demographic differences on youth behavioural intention to engage in agriculture, International Journal of Academic Research in Business and Social Sciences, 10(15), 284-291.

D'Silva, J. L., Samah, B. A., \& Shaffril, H. A. M. (2012). The march to sustainability of agriculture through contract farming-How will the youth fare? OIDA International Journal of Sustainable Development, 3(11), 59-66.

D'Silva, J. L., Samah, B. A., Shaffril, H. A. M., \& Man, N. (2011). Preservation of the environment through sustainable agriculture practices: A case study on the attitude of crop farmers. American Journal of Environmental Sciences, 7(3), 195.

D'Silva, J. L., Shaffril, H. A. M., Uli, J., \& Samah, B. A. (2010). Socio-demography factors that influence youth attitude towards contract farming. American Journal of Applied Sciences, 7(4), 603.

FAO. (2019). Transforming food and agriculture to achieve the sustainable development goals. Retrieved from http://www.fao.org/fao-stories/article/en/c/1184363/.

Harland, P., Staats, H., \& Wilke, H. A. M. (2007). Situational and personality factors as direct or personal norm mediated predictors of pro-environmental behavior: Questions derived from norm-activation theory. Basic and Applied Social Psychology, 29(4), 323-334.

Hussin, H., \& Noor, R. M. (2005). Innovating business through e-commerce: explore the willingness of Malaysian SMEs. In Proceedings of the 2nd International Conference on Innovations in Information Technology. Dubai, UAE.

Ismail, M. R. (2006). Pertanian Lestari (1st ed.). Kuala Lumpur, Malaysia: Dewan Bahasa dan Pustaka. Iwala, O. S. (2006). Assessment of youth-in-agriculture programme in Ondo state: Desireability and effectiveness. In G. E. Onibi, S. O. Agele, V. A. J. Adekunle, \& M. O. Akinbulumo (Eds.), Proceedings of the 2nd Annual Conference on Agricultural Research for Development in Nigeria (pp. 223-231). Akure, Nigeria.

Kendall, J. D., Tung, L., Chua, K., Ng, D., \& Tan, S. (2001). Receptivity of Singapore's SMEs to electronic commerce adoption. Journal of Strategic Information Systems, 10(3), 223-242.

Limthongchai, P., \& Speece, M. W. (2003). The effect of perceived characteristics of innovation on ecommerce adoption by SMEs in Thailand. In Proceedings of the 7th International Conference on Global Business and Economic Development. Bangkok, Thailand.

Mallapa, V. K. H., \& Babu, S. C. (2021). Building a resilient food system: Challenges and a way forward. In Mallapa, V.K.H, \& Shirur, M. (eds). Climate Change and Resilient Food Systems. Springer, Singapore.

Meyer, A., Gaba, V., \& Colwel, K. (2005). “Organizing far from equilibrium: Nonlinear change in organizational fields. Organization Science, 16(5), 456-473.

Ministry of Agriculture and Agro-based Industry. (2011). National Agro-food Policy (2011- 2020). Kuala Lumpur, Malaysia: Ministry of Agriculture and Agro-food Industry.

Obiniyi, A., \& Ibrahim, A. (2015). A Web-based farm 3D visualization management system. Computer Science Systems Biology, 8(1), 49-54. 
Pierce, F. J., \& Clay, D. (2007). GIS applications in agriculture. Boca Raton/London/New York: CRC Press.

Rathe, K., \& Witt, U. (2001). The nature of the firm-Static versus developmental interpretations. Journal of Management and Governance, 5(3-4), 331-351.

Rogers, E. (2003). Diffusion of innovations (5th ed.). Simon and Schuster.

Stewart, P. (2001). Complexity theories, social theory, and the question of social complexity. Philosophy of the Social Sciences, 31, 323-360.

Tan, K. S., Chong, S. C., \& Uchenna, C. E. (2009). Factors influencing the adoption of internet-based ICTs: evidence from Malaysian SMEs. International Journal of Management and Enterprise Development, 109 (2): 224-244.

Tan, M., \& Teo, T. S. H. (2000). Factors influencing the adoption of internet banking. Journal of the Association for Information Systems, 1(5), 1-42.

Taylor, J. R., \& Lovell, S. T. (2012). Mapping public and private spaces of urban agriculture in Chicago through the analysis of high-resolution aerial images in Google Earth. Landscape and Urban Planning, $x x x(x x x), 1-14$.

Teece, D. J. (2007). Explicating dynamic capabilities: The nature and microfoundations of (sutainable) enterprise performance. Strategic Management Journal, 28, 1319-1350.

Thompson, J., Millstone, E., Scoones, I., Ely, A., Marshall, F., Shah, E., \& Stagl, S. (2007). Agri-food system dynamics: pathways to sustainability in an era of uncertainty (Working Pape No. 4). Brighton, England: The STEPS Centre. Retrieved from http:// www.steps-

centre.org/PDFs/Final_steps_agriculture.pdf and http://www.steps-centre.org/PDFs/ final_appendix_agriculture.pdf.

Trujillo, P., Piroddi, C., \& Jacquet, J. (2012). Fish farms at sea: The ground truth from Google Earth. Plos One, 7(2), 1-4.

Urry, J. (2005). The complexities of the global. Theory, Culture and Society, 22, 235-254.

Vanclay, F., \& Lawrence, G. (1994). Farmer rationality and the adoption of environmentally sound practices: A critique of the assumptions of traditional agricultural extension. European Journal for Agricultural Education and Extension, 1(1), 59-90.

Walsh, J. P., Meyer, A. D., \& Schoonhoven, C. (2006). A future for organization theory: Living in and living with changing organizations. Organization Science, 17, 657-671. 